Letter from the Editor-in-Chief

目から鱗のマススペクトロメトリー

第 7 回「マススペクトルの横軸項目表記法」

〜Da は分子量の単位ではありません〜

\title{
Comments on Abscissa Labeling of Mass Spectra
}

\author{
吉野健一 1,2 \\ Ken-ichi Yoshino ${ }^{1,2}$ \\ 1 神戸大学バイオシグナル研究センター Biosignal Research Center, Kobe University, Kobe, JAPAN \\ 2 編集委員長 Editor-in-chief
}

\begin{abstract}
Mass spectrometers separate ions according to each mass/charge value, which is not a dimensionless quantity. However, the $m / z$ value indicated in the abscissa of mass spectra is defined as a dimensionless quantity and not a numerical value the same as the mass/charge value in kilograms/coulombs (kg/C). The numerical value of $\mathrm{m} / \mathrm{z}$ converted from the mass/charge value depends on the unified atomic mass unit, $\mathrm{u}$ (or dalton, Da) and the physical constant "elementary charge," $e$ that is also the atomic unit of charge. This conversion confuses many mass spectrometrists with regard to the abscissa labeling of mass spectra. To avoid this confusion, a new unit, "thomson" (unit symbol, Th), was proposed, and defined as $1 \mathrm{Th}=1 \mathrm{u}$ /atomic charge=1 Da/atomic charge. However, this unit is not yet well known and has been deprecated.
\end{abstract}

「目から鱗のマススペクトロメトリー」* 第 7 回はマススペクトルの横軸項目の表記法の問題点についてのこれまでの総 括と補足事項です。

「朝霧さん，これまであなたにはマススペクトルの横軸項目の表記について考えていただきました，その過程で，マスス ペクトルの横軸の数值が表している物理量や $m / z$ という記号, 質量電荷比という用語の問題, そして原子質量の単位の問 題についてお話してきました」

「はい，ありがとうございます」

「どういたしまして。であ扔礼は結構ですよ。これも私の大切な仕事ですから。そして，いろいろなことを朝霧さんにお 話していきながら，その過程で, 私自身む頭の中で何となく理解していた事象の整理もでき, 理解が深まったように思いま す。良い機会をいただいたと思っています」

「㧍役に立てたようで私も光栄です」

「朝霧さん，せっかくですから，マススペクトルの横軸項目の表記に関して，あなたが理解したことを簡単にまとめてく ださいませんか」

「はい，かしこまりました。

(1) マススペクトルの横軸の数值が表している物理量は $m / z$ であり, 質量, 質量数, 分子量などの物理量, 数量ではな いこと.

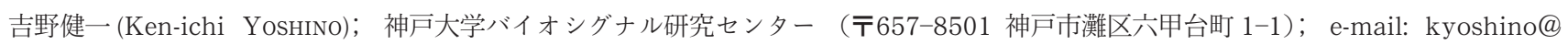
kobe-u.ac.jp

*「目から鱗のマススペクトロメトリー」は，明石海峡大橋の袂の小高い丘の上にキャンパスを構える明石大学，そこに設置された我が 国の大学で唯一の質量分析の研究を専門とする施設, 質量分析学研究所の Protein Mass Spectrometry 部門を主宰する垂水研一（た るみけんいち）博士と大学院生，朝霧舞子（あさぎりまいこ）さんとの研究打合せの際に交わされた会話を記録した形式で記述いたし ます。この登場人物および施設名は架空です。

本連載「目から鱗のマススペクトロメトリー」に関するご意見，ご質問は上記の宛先すしくは e-mail アドレスまでお寄せください。 略語, ESI: Electrospray Ionization（エレクトロスプレーイオン化), IUPAC: International Union of Pure and Applied Chemistry (国際純正・応用化学連合), RCM: Rapid Communications in Mass Spectrometry, SI: Le Systeme international d'unités (国際単 位系). 
Table 1. マススペクトルの横軸項目, $m / z$ 以外の表記例

\begin{tabular}{|c|c|c|c|c|c|c|c|c|}
\hline (?) & $m / z$ & $\cdots \quad(1)$ & $x$ & $m / z, a m u$ & $\cdots \quad(2)$ & $x$ & Mass/Charge & $\cdots \quad(3)$ \\
\hline$x$ & 質量/電荷 & $\cdots \quad(4)$ & $x$ & 質量電荷比 & $\cdots \quad(5)$ & $x$ & mass-to-charge ratio & $\cdots$ \\
\hline$x$ & 質量/電荷比 & $\cdots \quad(7)$ & $x$ & 電荷質量比 & $\cdots \quad(8)$ & $x$ & 質量/荷電 & $\cdots$ \\
\hline$x$ & 質量電荷比 $(\mathrm{m} / \mathrm{z})$ & $\cdots(10)$ & $x$ & Mass (m/z) & $\cdots(11)$ & $x$ & 質量 (m/z) & $\cdots(12)$ \\
\hline$x$ & 質量数 & $\cdots(13)$ & $x$ & 質量数 $(\mathrm{m} / \mathrm{z})$ & $\cdots(14)$ & $x$ & 質量数 (Da) & $\cdots(15)$ \\
\hline$x$ & 分子量 (m/z) & $\cdots(16)$ & $x$ & 分子量 (Da) & $\cdots(17)$ & $x$ & $\mathrm{u} / \mathrm{e}$ & $\cdots(18)$ \\
\hline$x$ & $\mathrm{Da} / \mathrm{e}$ & $\cdots(19)$ & $x$ & $m / z(\mathrm{Da})$ & $\cdots(20)$ & $x$ & $m / z(\mathrm{u})$ & \\
\hline$x$ & $m / z(T h)$ & $\cdots(22)$ & $x$ & $m / z=\left(M+\mathrm{nH}^{+}\right) / \mathrm{n}$ & $\cdots(23)$ & $x$ & {$[\mathrm{M}+\mathrm{H}]^{+}(\mathrm{m} / \mathrm{z})$} & $\cdots(24)$ \\
\hline
\end{tabular}

(2) $m / z$ は物理量であり，それゆえにイタリック体で表記しなければいけないこと.

(3) $\boldsymbol{m} / \boldsymbol{z}$ は, 荷電粒子の質量を統一原子質量単位 $\mathbf{u} て ゙$ 割って得られる無次元量を, 同じく無次元量である電荷数, すな わち当該荷電粒子の電気量を電気素量 $\boldsymbol{e}$ で割ることによって得られる無次元量であること. そして無次元量である $m / z$ には, 単位は不要であること.

(4) $m / z$ はあくまでも物理量であり単位ではないこと.

(5) 長い間慣用的に用いられてきた『質量電荷比』という用語は, 記号 $m / z$ が定義する物理量を正確に表していないこ と.

以上です」

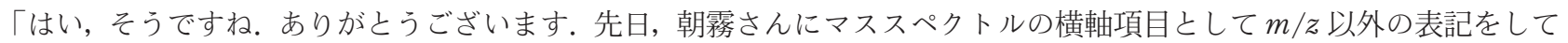
いる例を探していただきましたが，その際に作成したこの表 (Table 1)を見ながらもう一度それぞれの表記がなぜ不適切 なのかを復習してみましょう」

「はい」

「11の理由で不適切な表記はどれですか？」

「はい，少々持待ちください」

「たくさんあります.(3) から(19)までの表記すべてにこの理由があてはまります」

「そうです斌。それでは，(3)理由で不適切な表記はどれですか？」

「(2), (20), (21), (22)の 4 つです」

「はい. 次に, (4)の理由で不適切な表記はどれですか？」

$\lceil m / z$ を単位として表記している例ですので, (10), (11), (12), (14), (16), (24)の 6 例です」

「(5)の質量電荷比の問題力理由になるのは?」

「(1)の理由と重なるものもありますが, (3) から (7)の 5 つと, (10)でしょうか？ (8)の『電荷質量比』之, (9)の『質量/ 荷電』は, この理由には当てはまらないように思います」

「そうですね。電荷質量比』という言葉, 別の表現を使えば『比電荷』です. 質量を $m$, 電荷を $q$ とすれば, 質量電荷比 は $m / q$ で, 単位は $\mathrm{kg} / \mathrm{C}$ ですが, 電荷質量比, 比電荷はその逆数になりますので, $q / m$ 之表すことができ, 単位は $\mathrm{C} / \mathrm{kg}$ です.したがって, 電荷質量比は, 数值としては質量電荷比とは異なります. あち万ん, マススペクトルの横軸が表してい る数值であありませんので，マススペクトルの横軸項目として表記することは䛊りです」

\section{電荷と荷電}

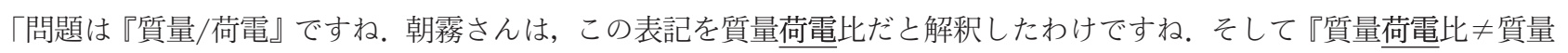
電荷比』であると」

「はい」

「漢字の表記の順序は異なりますが, 荷電と電荷とは同じ意味だと思います。しかし，念のために調べてみましょう，化 学大辞典1 ${ }^{1}$ を調べていただけますか。私は理化学辞典 ${ }^{2}$ を見てみます」

「はい，少々持待ちください」

「垂水先生, 化学大辞典には『電荷』という項目は収録されていますが,『荷電』という用語は収録されていません. 理化 学辞典のほうはいかがでしょうか?」

「理化学辞典には, 『荷電』という用語は見出し語としては収録されていますが,『電荷』を引きなさいとなっています。 『電荷』を見てみます」 
「朝霧さん, 『電荷』の解説文の中にはこのような説明があります.『素粒子はその種類によってきまる一定の電気量をも

ち, 電気素量を $e$ とすれば, $0,+e,-e$ のいずれかである。この種の電荷は荷電とよばれることが多い』」

「どういう意味でしょうか?」

「電荷という用語自体は広い意味をもっていますが, 荷電という用語は, 荷電粒子という用語に代表されるように, 語感 としては素粒子やイオンなどの粒子があっている電荷のことや粒子が電荷をあつことを指しているように思います。ただ し日本語の用語として, 科学的に明確な定義がされているわけではありませんので, ほぼ同義語と考えてあ良いのではな いでしょうか. 英語では電荷も荷電も electric charge むしくは charge です」

「また，質量分析はイオンを測定の対象としていますので, 荷電という用語が粒子のもっている電荷という意味に限定さ れるとしてあ, イオンに対して『質量/荷電』という言葉を用いること自体は間違いではないように思います.しかし, 『質 量電荷比』と同様の理由で『質量/荷電』をマススペクトルの横軸項目として表記すること自体は不適切です」

\section{$\mathrm{H}^{+}$は『プロトンの質量』を表す記号ではありません}

「垂水先生, (23) の『 $/ \mathrm{m} / \mathrm{z}=\left(\mathrm{M}+\mathrm{nH}^{+}\right) / \mathrm{n} 』$ の表記は, なぜ不適切なのでしょうか ? この表記, $m / z$ がイタリックで表 記されていないこと以外にも不適切な理由があると思いますが，その理由を説明できないのです。この表記では， $m / z$ と $\left(\mathrm{M}+\mathrm{nH}^{+}\right) / \mathrm{n}$ が等号で結ばれています. 確かに $m / z$ の值を求める際にはこの方程式を使って計算しますので, この数式自 体に誤りはないと思います。この表記が不適切である理由は，スペクトルの横軸項目を方程式として表しているからで しょうか?」

「そうですね.グラフそのむのではなく，グラフの座標の項目を，方程式を使って表記している例をあまり見かけません が，どんな物理量をプロットしているのかが明確にわかるのであれば問題はないと思います。しかしこの例ではどうで しょうか？ 素直に読みとれば左辺の $m / z$ でしょうか？ しかし，この式が横軸項目を表記しているあのではなく， $M$ と $n$ の二つの変数をプロットしたグラフ自体の式を表していると解釈されるかもしれません．紛らわしいという点では適切 ではないと思います」

「ところで朝霧さん，この数式，右辺と左辺とは同じ意味ですか？等号で結ぶことができますか？」

「多プロトン付加分子の $m / z$ の值を計算する際にはこの方程式を使って計算しますが? この方程式に何か誤りがある のでしょうか?」

「朝霧さん，これ方程式ですか?」

「方程式ではないのでしょうか? ?

「これが方程式だとするならば， $\left(\mathrm{M}+\mathrm{nH}^{+}\right) / \mathrm{n}$ は $\left(\mathrm{M}+\mathrm{nH}^{+}\right) \div \mathrm{n}$ ですね。間違いないでしょうか ?」

「はい」

「それでは $\mathrm{n}$ は何の記号ですか？」

「一分子あたりに付加しているプロトンの数を表す記号です」

「そうですね。この $\mathrm{n}$ は， 1 か 2 か 3 かはわかりませんが，ある自然数です。それでは， $\left(\mathrm{M}+\mathrm{nH}^{+}\right)$は何の記号でしょう か?」

「多プロトン付加分子の質量です」

「そうでしょうか？ 朝霧さんが言うように， $\left(\mathrm{M}+\mathrm{nH}^{+}\right)$が多プロトン付加分子の質量を表す記号であるとするならば， $\mathrm{M}$ は『分子の質量』であり, $\mathrm{H}^{+}$は『プロトンの質量』を表す記号になります.です $\mathrm{H}^{+}$は『プロトン』を表す記号ですが, 『プロトンの質量』を表す記号ではありません． $\mathrm{H}^{+}$がプロトンの質量を表す記号であるならば，『H $\mathrm{H}^{+}=1.67262171(29) \times$ $10^{-27} \mathrm{~kg}$ ¿書いても問題ないということになります。通常, 質量の記号として使われる文字は小文字の $m$ で，物理量で すからイタリック体にします。またプロトンの質量は通常 $m_{\mathrm{p}}$ という記号が使われます。しかし，必ずこの記号にしなけれ ばいけないという決まりはありません。定義をする必要はあります。あし $\mathrm{H}^{+}$をプロトンの質量という特定の物理量を表 す記号として用いたいのであ杖，必ず定義をして使用しなければいけません．しかし， $\mathrm{H}^{+}$は通常，プロトンそのものの 記号として，化学式などに用いられていますので，これを数式の中でプロトンの質量という物理量の記号としても使用す ることは好ましいことではありません，M あ同様です．これを分子の質量という物理量，変数の意味で使用するのであれ ばあらかじめ定義をする必要がありますが，ここでは $\mathrm{M}$ あ $\mathrm{H}^{+}$あ, 分子やプロトンそのあのを表す化学種としての記号 と，それぞれの質量を表す記号という 2 種類の異なる概念の意味をあたせて使われています」

「ご指摘のと抢りですね」

「したがって, $\left(\mathrm{M}+\mathrm{nH}^{+}\right)$は多プロトン付加分子自体, 化学種を表す記号として使っているのであれば, 多プロトン付加 分子の質量という物理量を表す記号として利用してはいけません。せめてイタリック体で表記するなどして区別すればよ いのですが. (23)の表記が適切ではない理由の一つは， $\left(\mathrm{M}+\mathrm{nH}^{+}\right)$を多プロトン付加分子の質量という物理量を表す記号 として用いている点です」

「でも，朝霧さん，今の話は少々杓子定規なことですので，それほど深刻に考える必要はありません．頭の片隅で結構で 
すから何となく覚えておいてください」

「はい」

\section{ESI で観測されるイオンは（多）プロトン付加分子だけではありません}

「これらの理由よりあ大きな問題を (23) の表記は抱えています. 朝霧さん, 質量分析において観測されるイオンの種類に はどのような種類がありますか?」

「以前教えていただきましたが，プロトン付加分子，脱プロトン分子，分子イオン，ナトリウムイオン付加分子，多プロ トン付加分子などです」

「そうですね。質量分析で観測されるイオンには，いろいろな種類があり，プロトン付加分子や多プロトン付加分子だけ ではありません」

「垂水先生，わかりました。、マススペクトルの横軸項目に $\left(\mathrm{M}+\mathrm{nH}^{+}\right)$と記載し，このマススペクトルで観測されているイ オンをプロトンが付加して生成したイオンだけであると，イオンの種類を特定してしまっていることが問題なのではない でしょうか?」

「そのと抢りです。拉そらく(23) の表記があったマススペクトルはエレクトロスプレーイオン化 Electrospray Ionization (ESI) 法によって測定されたものだとは思いますが，ESI を利用した質量分析において観測されるイオンのすべてが プロトン付加分子ではありません。ナトリウムイオンなどの他のカチオンが付加して生成したイオンが観測されていない ことを完全に否定することはできないのではないでしょうか (Fig. 1).プロトンが付加して生成したイオンだけを対象とし

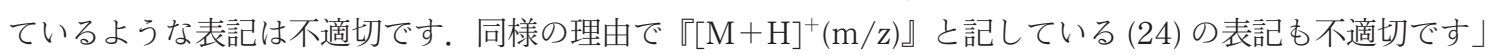

「そうですね」

$\Gamma(24)$ の表記にも複数の誤りがあります. 今拉話したイオンの種類を $[\mathrm{M}+\mathrm{H}]^{+}$のみに限定してしまっている点, $m / z$ を 単位だと誤解している(4)の理由むあります。そしてあう 1 点不適切な理由があります」

「どのような理由でしょうか?」

「この表記をした人は $m / z$ を単位であると誤解しているわけですが，たとえ $m / z$ が単位だとしてもおかしいのです．先 程の数式の右辺の表記法の誤りに似た誤解です. $\left(\mathrm{M}+\mathrm{nH}^{+}\right)$が多プロトン付加分子の質量という物理量を示す記号ではな いのと同様に, $[\mathrm{M}+\mathrm{H}]^{+}$あプロトン付加分子の質量を表す記号ではありませんので， (24)のように $[\mathrm{M}+\mathrm{H}]^{+}$という表記 だけでは，プロトン付加分子のどんな物理量を表示しているのかを明確に示したことにはならないのです」

「なるほど，そうですね」

「朝霧さん，須磨の海浜水族園に行かれたことがありますか？」

「はい，大好きな場所です」
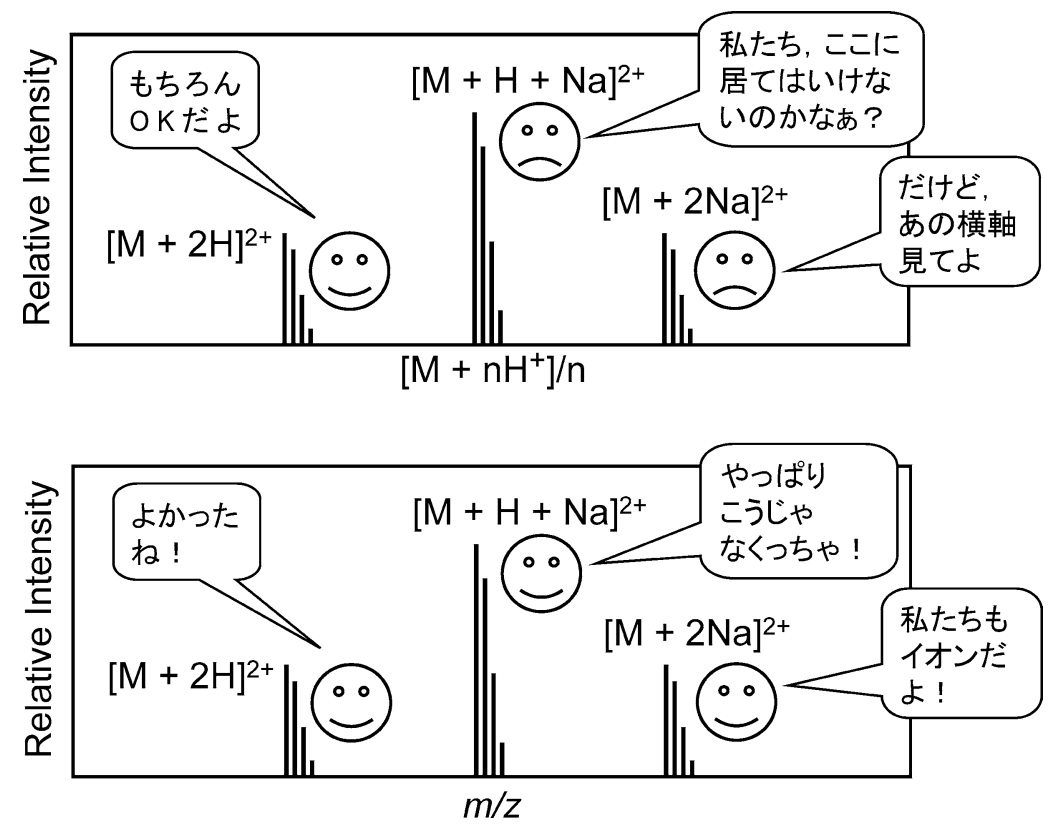

Fig. 1. 質量分析で観測しているのは，プロトン付加分子や多プロトン付加分子だけではありません. $[\mathrm{M}+2 \mathrm{H}]^{2+}: 1$ 分子に，二つ のプロトンが付加して生成した二価イオン; $[\mathrm{M}+\mathrm{H}+\mathrm{Na}]^{2+}: 1$ 分子に, プロトンが一つ, ナトリウムイオンが一つ付加し て生成した二価イオン; $[\mathrm{M}+2 \mathrm{Na}]^{2+}: 1$ 分子に，二つのナトリウムイオンが付加して生成した二価イオン 
「須磨の海浜水族園には『クー』と名づけられた雌のハンドゥイルカ† Tursiops truncatus がいます．例えば，このクー の身長を毎日測定し，横軸に測定日を，縦軸に身長をプロットしたグラフを作成したとしましょう」

「はい」

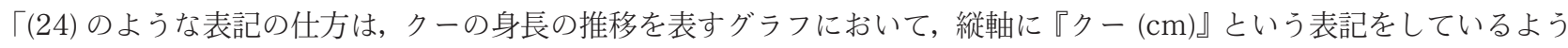
な屯のなのです，この表記ではクーの何の長さの值なのかは判断できません. クーの身長なのか, ク一の前肢, 胸ビレの長 さなのか，クーがジャンプした際の到達点の水面からの高さなのか， $\mathrm{cm}$ を単位として表記できるあのはたくさんありま

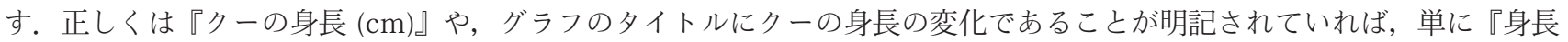
(cm)』とすべきです」

「イルカの名前のような具体的な固有名詞でしたら，このような䛊りをしにくいと思いますが，固有名詞ではない場合は 気づきにくいかもしれません」

$\left\lceil[\mathrm{M}+\mathrm{H}]^{+}\right.$は， あくまであプロトン付加分子を示す記号であり， プロトン付加分子の質量という物理量を表す記号では ありません，表記の際には，変数としての物理量の名称なのか，そ机外の呼称なのか，よく考えなくてはいけません」

「垂水先生，この表記をした人は $m / z$ は単位ではなく物理量であることをわかったうえで，括弧の中に $m / z$ と記し， 『[M $+\mathrm{H}]^{+}$の $m / z$ の值』という意味でこの表記をしているのではないでしょうか ?」

「むしそうだとしても, 通常, グラフの軸項目において括弧の中に記された文字は単位を表していると理解されますの で, 括弧の中に物理量を示す記号を表記してはいけません，ましてやこの $(24)$ の例では, $\mathrm{m} / \mathrm{z}$ とイタリック体で書いてい ませんので, $m / z$ を物理量であると理解してこの表記をしているとは思えません」

「マススペクトル以外にも, このように, どんな物理量を, どんな変数をプロットしたのかがわからない軸項目の表記を しているグラフを時折見かけます。 グラフを作成した人は，何の疑いむもたずにこのような表記をしているのだろうと思 いますが, 明らかな思いこみです将、書いた後にもう一度見直して，第三者の立場でグラフを眺めて見机，おのずからこ うした自身の思いこみに気づくのではないでしょうか. ただし，人間，誰しも思いこみはありますから，そういう私も気を つけないと」

「私も気をつけます」

\section{単位ダルトン $(\mathrm{Da})$ について}

「垂水先生, $(18)$ の『u/e』と (19) の『Da/e』ですが, $m / z$ 以外の表記をしていますので, 不適切であることは間違いな いと思います。しかし，この表記が不適切である理由，そしてどのような誤解によってこの表記をしているのか，わかりま せんでした」

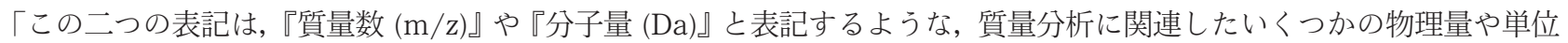
を混同した初歩的な誤解ではなく，マススペクトルの横軸が表す物理量について，そして $m / z$ という記号や質量電荷比と いう用語の定義に関する問題点について，それなりに熟慮した結果だと思います」

「これらの表記をした方はどのように考えられたのでしょうか?」

「表記に関する説明をする前に，まず Da という単位記号について括話します」

「はい，抒願いします」

$\lceil\mathrm{Da}$ は，統一原子質量単位 unified atomic mass unit, u と同様に質量の非 SI 単位である dalton の単位記号です。この 単位, 日本語では『ダルトン』, もしくは『ドルトン』と呼ばれています. Da は, 現在, 統一原子質量単位 u に等しいと定 義されています。すなわち $m\left({ }^{12} \mathrm{C}\right)=12 \mathrm{Da}=12 \mathrm{u}$ です」

「私もそのように理解しています」

「朝霧さん, でも Da という単位, これまで多くの方々が統一原子質量単位 u と同義の単位として用いていましたが, 実 は，この使い方， 2006 年まではあくまであ慣用的な使用法だったのです」

「正式に定義され，国際的に承認された単位ではなかったということでしょうか？」

「そのと扔りです．分子の相対質量を表す数量として分子量という概念があります対」

「はい」

「分子量は, 分子の大きさの目安にあ利用されますが, Da という単位, 元々は, 染色体やウィルス, ミトコンドリア, リ ボソームなどの巨大分子複合体や分子の会合体など，分子量の概念をあてはめることができない超分子構造体の大きさを 表現する適当な方法がなかったことから提案された単位でした ${ }^{3)}$ ). 数值的には分子量と同じスケール, 同じ尺度で超分子 構造体の質量の概算值，推定值を表記する場合に限定して使用されていたようです」

†一般には「バンドウイルカ」と呼ばれているが，正式な和名は「ハンドウイルカ」である，漢字で表記すると「半道海豚」. ただし， 学術的には学名 Tursiops truncatus が唯一の正式な呼称であり，これを䛊記することは許されないが，和名はあくまであローカルな 通称であり,「バンドゥイルカ」と呼んであ別種のイルカが䚻属されるわけではないので誤りではない. 
「垂水先生, ぞうして分子の複合体や会合体の大きさを表現するために分子量という用語を使用してはいけないので しょうか？ 分子の複合体や会合体に分子量の概念をあてはめることができないのでしょうか？」

「理由は簡単です. 分子量はその名の之扤り分子を対象として定義された概念だからです. 分子ではないものに分子量の 概念を適用できません，塩化ナトリウム $\mathrm{NaCl}$ などの無機イオン結晶物質に対して分子量の概念をあてはめることができ ないことと同じ理由です。無機イオン結晶物質に対しては, 分子量に相当する用語として式量, または化学式量という用語 があります」

「高校時代に教わったような，かすかな記憶があります」

「化学大辞典1)で調べていただけますか?」

「はい，少々お待ちください。

\section{化学式量 [chemical formula weight]}

式量 (formula weight) ともいう，化合物の組成を化学式で表したとき，その中に含まれる原子の相対原子質量の総 和. 化合物が水やメタンのように分子であれば, 式量は分子量（相対分子質量）に等しい，無機物の結晶のように, 分子が一単位としては存在しないとき，分子式の代わりに組成式が用いられる．これを質量にして表現するのが式 量であり，分子量よりあ広義に用いられる。たとえば食塩の結晶中には分子は存在しないが $\mathrm{NaCl}$ は組成を示し， $\mathrm{Na}$ と $\mathrm{Cl}$ の相対原子質量の和 58.5 が化学式量である.

以上です。思い出しました」

「分子量自体は相対値なので単位はありません。したがって, 超分子構造体に対して, 分子量と同じ尺度で比較するため の数量を導入する際に, 新たな定義は必要ですが, 新たな単位は必要ないと思います. 分子量の概念をあてはめることがで きない超分子構造体全体の大きさを表現する適当な方法がなかったという理由で『Da』という単位が提案されたこと自 体, 私は理解に苦しむのです. $\mathrm{NaCl}$ の式量に単位がないのと同様に, 超分子構造体の大きさを表す概念にも単位は必要な いはずです」

\section{「そうです权」}

「超分子構造体に分子量の概念を適用することはできません．また翻訳後修飾基のない少数のタンパク質からなる複合 体であれば化学組成式がわかることああるかむしれません。その場合は式量の概念を適用することあ可能でしょう。しか し, リボソームやミトコンドリアなど, 多種多様な分子から構成されている超分子構造体の分子組成を正確に解析し, 化学 組成式を特定することは不可能でしょうから, このような超分子構造体の大きさを分子量と同じスケール比較するために は，確かに別の概念，定義が必要になってきます」

「でもそのために Da という単位が考案されたのでしょうか?」

「質量分析レベルの正確な質量の測定値を求めることはできなくても, 統一原子質量単位 $\mathrm{u}$ や, 時代によっては過去の単 位である $\mathrm{amu}$ のような, 原子質量の単位を用いて, 概算值で超分子構造体全体の質量を表記しても問題はないと思うので すが，なぜ Da が考案されたのか理由はわかりません」

「現在, Da の単位量は統一原子質量単位 $\mathrm{u}$ と等しいと考えられていますが, この単位がいつ頃提案されたのか, 私は知 りません。 あし, Da という単位が提案された時期が 1960 年代初頭の統一原子質量単位制定よりあ前であったならば, 提

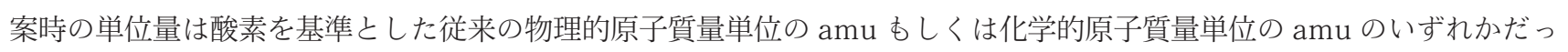
たことも考えられます. 原子質量の単位の基準元素が酸素から炭素に移行した後は, Da の単位量も自然に移行していった のでしょうか．私自身，Da という単位を定義した原著や，その後の経緯を文献的に理解しているわけではありませんの で，単位の明確な定義や現在のような使用法に変わっていった詳しい経緯など，はっきりしたことはわかりません，そし て, Da は, 本来単位を必要としない分子量の単位として誤用され，何となく慣用的に使わ机てきた少々暧昧な単位という 印象をむっていました」

「確かに『分子量 $66 \mathrm{kDa}$ のような表記はよく見かけます。これは誤用なのでしょうか？」

「明らかな誤用です. 分子量には単位はありませんので,『分子量 $66 \mathrm{kDa}$ ではなく, 有効桁が 2 桁であれば『分子量 66 $\times 10^{3}$ 』表記しなければいけません」

「Da が使用されていた対象が, 元々は生体関連分子からなる超分子構造体であったことから, 生物科学の領域において, 慣用的に超分子ではない単体の生体関連分子の質量の単位としても使用されるようになったようです。生体関連分子に用 いられるケースでは, 分子量の単位として用いられる誤用も多いのですが, 質量の単位としても用いられてきました。 あち 万ん単位量は統一原子質量単位 $\mathrm{u}$ と同じです.したがって, 同一の単位量に 2 種類の名称, 単位名が存在することになり, 知名度は Da のほうが上だったかむしれませんが，Daの使用が歓迎されないこともありました」

「私も，統一原子質量単位 $\mathrm{u}$ や $\mathrm{amu}$ よりも Da を先に知ったように思います」

「知名度の高さからでしょうか，2006 年 Bureau international des poids et mesures 国際度量衡局が発行した国際単位 系 SI の国際文書第 8 版 51 , 6) において, SI との併用が認められている質量の単位として, 統一原子質量単位 uに加え, 新た に Da が収録されました。したがって, 今後は Da を統一原子質量単位 $\mathrm{u}$ と全く同じように使用しても問題はないと思いま 
す」

「Daは国際的に承認された単位となったわけでしょうか？」

「そうですね。これほど幅広く使用されていますので，使用しないよう勧告するよりは，明確な定義をしたうえで正確に 厳密に使用してもらったほうが多方面にわたって混乱が少ないと判断したのでしょうか。勘違いされたら困るのですが, SI との併用が認められている質量の単位として正式に収録されただけであって, 分子量の単位として承認されたわけでは

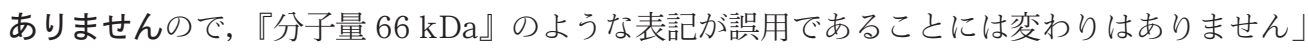

\section{『u/e』と『Da/e』}

「以前, 質量電荷比という用語について, この語句を文字どおりに解釈すれば, 荷電粒子の, キログラムの単位をあつ有 次元の物理量である質量 $m$ を, クーロンの単位をむつ有次元の物理量, 電荷 $q$ で割ることによって得られる商なので, マ ススペクトルの横座標が表す数值である, イオンの質量を統一原子質量単位 uで割って得られる無次元量を, さらに同じ く無次元量であるイオンの電荷数で割ることによって得られる無次元量 $m / z$ を表す用語としては適当ではない, というお 話をしました7)」

「はい」

「マススペクトルの横座標に表される数值が示す $m / z$ 之いう物理量は, 無次元量であると定義されていますが, 感覚的 に $m / z$ が無次元量であるということを納得できない人むいるのではないかと思います. 統一原子質量単位 $\mathrm{u}$ を用いて表し たとしても質量は質量であり, 質量という物理量を無次元量であると誰も思っていません. イオンがあっている電荷, 電気 量も電気素量の整数倍ですし, 電荷も無次元量であると誰も思っていません. したがって, 両者を割っても次元が消えるわ けはなく, 『質量電荷比』という用語があつ概念が影響して, 感覚的に $m / z$ が無次元量であるということを納得できないと 思います」

「質量分析に扔いて, 感覚的に次元のある数量を測定しているのにあかかわらず, $m / z$ に単位をつけることができないと いうことにジレンマを感じている人もいるのではないかと思います」

$\lceil 『 \mathrm{u} / \mathrm{e} 』 や 『 \mathrm{Da} / \mathrm{e} 』 と い う$ 表記は, どうしたらマススペクトルの横座標が表す数值に単位を付けて表記できるのか, 次元 をもたせることができるのかを熟慮した結果だと思います」

「しかし，残念ながら，これらの表記にも不適切さが残っています」

「どのような点が不適切なのでしょうか?」

$「 2$ 種類の理由があります。一つは, スペクトルの横座標は変数である物理量が表記されていますので, 項目としては変 数である物理量の名称もしくは記号を表記する必要がありますが, 『u/e』や『Da/e』という表記ではこの条件が満たされ ていないことです．朝霧さん， uや Da は何の記号ですか?」

「はい，u は統一原子質量単位，Da はダルトンの単位記号です」

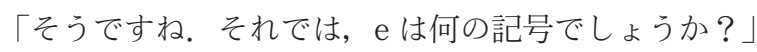

「電荷の記号として用いられることあありますが, この場合は素電荷, 電気素量の記号として用いられているのではない かと思います」

「そうですね.イタリック体ではないので電子の記号とも考えられますが, マススペクトルの横軸項目として表記されて いますので，扔そらく，朝霧さんの推察ど抢り電気素量 $e$ だと思います」

「電気素量 $e$ は変数ではなく物理定数です。一方, uやDa は単位です。いずれも变数ではありません」

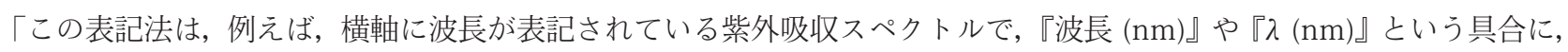
波長という変数の物理量を表示していることを明記せずに, 単位の『nm』とだけ表記することと同じ誤りです. 紫外吸収 スペクトルであることが図のタイトルなどで明確に表示されていれば紫外線の波長であることを理解することができます

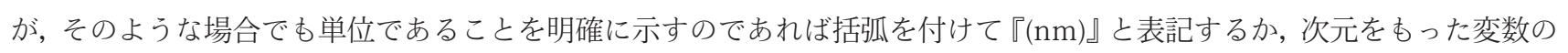

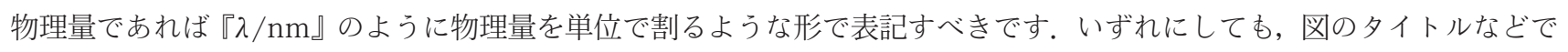
明確に表示されていたとしても, スペクトルやグラフを単独で見ただけで, それぞれの座標がいかなる变数, いかなる物理 量をプロットしたものかが容易に判断できる，また誤解を生じさせないような表記がなされるべきです，単位記号か物理 量の記号かはイタリック体で表記されているか否かで判断することもできますが，物理量であってもイタリック表記され ていない場合も多いので困ります」

「この場合は, 『(u/e)』や『( Da/e)』という具合に，括弧の中に入れて表示させれば問題はないでしょうか? 」

「横軸項目に括弧む付けずに単位を単独で表記することは適切とは言えませんが, 図のタイトルなどで, 横軸にどんな物 理量をプロットしたのかが明確にわかる記述がされていたとしても, u/eや Da/e の場合, 括弧の中に入れて単位として表 記すれば問題はないのかというと，それであまだ問題が残っています，それが二つ目の理由です，u/eや Da/e は単位とし ても不適切なのです」

「eがイタリック表記されていないからでしょうか？」 
「いいえ。これらの表記をした方々は, 質量分析計はあくまでも荷電粒子の質量と電荷の比を測定していて, 質量は統一 原子質量単位 $\mathrm{u}$ や Da の $m$ 倍として表記できる質量であり, 電荷は電気素量 $e$ の $z$ 倍として考えたのではないかと思いま す.そしてこの $m$ と $z$ の值の比 $m / z$ がマススペクトルの横軸にプロットされている数值であると考えたわけです」

「はい」

「すなわち, 正の電荷をむった荷電粒子の質量を $M \mathrm{~kg}$, その電荷を $Q \mathrm{C}$ とした場合, 質量電荷比の数値を $M / Q$ と表す ことができます权」

「はい」

「この $M / Q$ の単位は $\mathrm{kg} / \mathrm{C}$ です。質量 $M \mathrm{~kg}$ を $\mathrm{kg}$ ではなく, 統一原子質量単位 $\mathrm{u}$ や Da を使って表記した場合, $M \mathrm{~kg}=m \mathrm{u}$ ，あしくは $M \mathrm{~kg}=m \mathrm{Da}$

と置くことが可能です。一方, 電荷のほうは

$$
Q \mathrm{C}=z \times e
$$

と置くことが可能です．したがって，質量電荷比 $M / Q(\mathrm{~kg} / \mathrm{C})$ を,

$$
M / Q(\mathrm{~kg} / \mathrm{C})=\frac{m \mathrm{u}}{z e} \text { や, } M / Q(\mathrm{~kg} / \mathrm{C})=\frac{m \mathrm{Da}}{z e}
$$

と書き表すことができます。これは

$$
M / Q(\mathrm{~kg} / \mathrm{C})=(m / z) \times(\mathrm{u} / e) \quad \text { や, } M / Q(\mathrm{~kg} / \mathrm{C})=(m / z) \times(\mathrm{Da} / e)
$$

と形を変えることができます. $m$ と $z$ が変数ですので, $\mathrm{u}$ や Da や $e$ が単位であれば $m / z$ という变数の単位が $\mathrm{u} / e$ や $\mathrm{Da} / e$ であると考えることもできます. (18)の『u/e』と(19)の『Da/e』という表記は, このような考え方に基づいてマススぺ クトルの横軸に記したのだと思います，この考え方に何ら問題がなければ， $m / z$ 之質量電荷比の問題は一気に解決すると 思います」

「垂水先生，皆さんにそのようにお鹰めでき机ば良いのでしょうが，きっとできない理由が何かあるのでしょうね」

「そうなのです. 残念ながら, 電気素量 $e$ は物理定数であって単位ではないのです. 撖密な言い方をしますと, 電気素量 $e$ は, 原子物理や量子化学で用いられている原子単位系 atomic units の一つの単位として利用されている非 SI 単位です が, 国際単位系とは全く異なった量の体系を基礎としているという理由で国際度量衡委員会 Comité International des Poids et Mesures は国際単位系との併用を正式に認めていないのです. それゆえに, 単位としては, u/eや Da/e という組 立単位を用いることは許されないのです」

「プロトンを例に挙げてもう少し具体的に考えてみましょう。プロトンの質量 $m_{\mathrm{p}}$ を $\mathrm{kg}$ の単位を用いて表せば

$$
m_{\mathrm{p}}=1.67262171(29) \times 10^{-27} \mathrm{~kg}
$$

です． $m_{\mathrm{p}}$ を $\mathrm{u}$, むしくは Daを用いて表記する場合は, $1.67262171(29) \times 10^{-27} \mathrm{~kg}$ を統一原子質量単位 $\mathrm{u}$ の単位量 1.660538 86(28) $\times 10^{-27} \mathrm{~kg}$ で割れば良いわけです.この計算によって, プロトンの質量は, 小数点以下 6 桁までで計算 した場合

$$
m_{\mathrm{p}}=1.007276 \mathrm{u}, \text { あしくは } m_{\mathrm{p}}=1.007276 \mathrm{Da}
$$

と表すことができます」

「はい」

「朝霧さん，プロトンの電荷 $q_{\mathrm{p}}$ を電気素量 $e$ の倍数として表してください」

「はい, プロトンの電荷 $q_{\mathrm{p}}$ は電気素量 $e$ の值と同じで $1.60217653(16) \times 10^{-19} \mathrm{C}$ ですので,

$$
q_{\mathrm{p}}=1 \times e
$$

となります」

「そうですね.したがってプロトンの質量電荷比 $M / Q(\mathrm{~kg} / \mathrm{C})$ は

$$
\begin{aligned}
& M / Q(\mathrm{~kg} / \mathrm{C})=1.007276 \mathrm{u} \div(1 \times e)=1.007276 \times(\mathrm{u} / e), \quad \text { あしく } \\
& M / Q(\mathrm{~kg} / \mathrm{C})=1.007276 \mathrm{Da} \div(1 \times e)=1.007276 \times(\mathrm{Da} / e)
\end{aligned}
$$

と書き表すことができます。この 1.007276 という数值は，マススペクトルの横軸に表示される数值そのあのです。こう してみると $\mathrm{u} / e や \mathrm{Da} / e$ は一見単位のように見え，ママススペクトルの横軸に表される数值が次元をもった值のように見え ます.しかし, 残念ながら, 先程も言いましたが, 電気素量 $e$ は物理定数として扱う必要があり, 国際単位系との併用は認 められていませんので, u/eや Da/e を単位として扱うことはできないのです」

「屯し, 電気素量 $e$ が国際単位系との併用が可能な単位として承認されれば, $\mathrm{u} / e$ や $\mathrm{Da} / e$ は $m / z$ 単位として用いるこ とができるのでしょうか?」

「いいえ, $m / z$ ではなく, 質量電荷比 $m / q$ の単位です. 混同しやすいのですが, マススペクトルの横軸に表記される $m / z$ の $m$ 之, 質量電荷比という物理量の記号 $m / q$ の $m$ とは, 表している物理量の単位が異なるのです. 質量電荷比 $m / q$ の $m$ のほうが一般的な使い方をしているのですが，それゆえに， $m / z$ の記号は $m$ 之 $z$ をそれぞれ分けて定義せずに, $m / z$ の 3 文字の記号として定義をしているのです」 
$\Gamma$ 「 1 点, $m / z$ には負の数值は存在しませんが, 質量電荷比 $m / q$ には負の数值ああり得ます. u/e や $\mathrm{Da} / e$ を単位とし た場合は負の数値になることああります」

「比電荷の単位は $\mathrm{C} / \mathrm{kg}$ です. また速さの単位は $\mathrm{m} / \mathrm{s}$ です. キログラム $\mathrm{kg}$ も, メートル $\mathrm{m}$ あ, 秒 $\mathrm{s}$ あ $\mathrm{SI}$ 単位です. クー

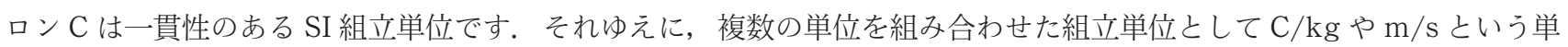
位を使用することは可能です. 統一原子質量単位 $\mathrm{u}$ や Da は国際単位系との併用は認如れていますが, 電気素量 $e$ は認 められていません，それゆえに， u や Daのような併用が認められている単位と組み合わせて，組立単位として用いること はできないのです」

$\lceil 『 \mathrm{u} / \mathrm{e} 』 や 『 \mathrm{Da} / \mathrm{e} 』 と い う$ 表記, e は単位であることを主張するために, わざとイタリック体になっていないのかあしれ ません，電気素量 $e$ が，国際単位系との併用が承認されれば，無次元量として定義しなければならない $m / z$ を使用しなく てもすむのですが, 残念ながら現時点は認められていませんのでしかたがありません.これを認めていただくためには, 質 量分析学の関係者どうしはもちろんのこと, 質量分析学以外の各分野の専門家との間で, しかも国際的な場で, 議論を積ん でいく必要があります. 来るべき議論の機会の到来に備えて, 私たちも単位系のことをもっともっと学び, 論理的な議論が できるようにならなければいけません」

「屯し承認された場合, $m / z$ を使用しなくなるのでしょうか?

「現在利用している $m / z$ 之同じ数值を, 質量電荷比 $m / q$ として扱うことが可能となりますので, 必要ないかすしれませ ん。ただし負の数值も扱うことにはなりますが」

「であ，質量分析に携わっている方々が，簡単に $m / z$ の使用をやめるでしょうか?

「朝霧さんの言うとおりかすしれません， $m / z$ と質量電荷比 $m / q$ との違いを明確に認識し, 混同さえしなければ, $m / z$ を無次元量として使用する現状の方法が賢明かもしれません」

\section{新単位 thomson, Th の提案}

「電気素量 $e$ が単位として SI との併用が認められないのであれば, 『u/e』や『Da/e』が組立単位として承認されないの であ机ば, ということを考えられたかどうかはわかりませんが, 1991 年, Cooks と Rockwood ${ }^{8}$ は『thomson』という新 しい単位を提案しました ${ }^{9)}$. 朝霧さん, この単位, ご存じですか？」

「垂水先生，1991 年ですから，かなり前のことですが， thomson という単位があること，初めてうかがいました」

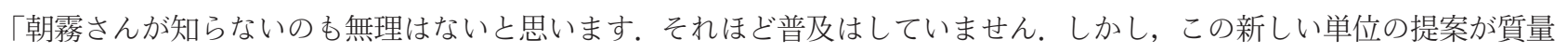
分析学の速報誌 Rapid Communications in Mass Spectrometry (RCM) に掲載された Letter to the Editor によってなされ たこともあっで，この RCM の Instructions to Authors には thomson の使用を認める記述があります」

「垂水先生, thomson という単位はどのような単位でしょうか?

「大切なことを言い忘れていました. thomson, 単位記号は『Th』です. 朝霧さんが作成した表 (Table 1) の (22)の表記 例にあった単位記号です。この単位の定義ですが，原文では

$1 \mathrm{Th} \equiv 1 \mathrm{u}$ /atomic charge

と記されています. $1 \mathrm{u}$ /atomic charge $=1 \mathrm{Da} /$ atomic charge です. しかし, uや Daは問題ないのですが, atomic charge という用語の定義がなく, 暧昧で良くわからないのですが，1価の負イオンの atomic charge は -1 とされていま すので, 電荷数 $z$ の值に正負を考慮した数值でしょうか. 1 Th の絶対值は, 通常われわれが用いている $1 \mathrm{~m} / \mathrm{z}$ unit の数值

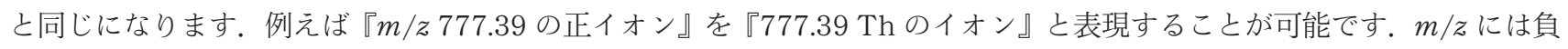
の值はありませんが, Thには負の值があります. $m / z 121.03$ の負イオンの場合は『-121.03 Th のイオン』という表現に なります」

「垂水先生, 例えば $m / z 777.39$ のイオンと $m / z 777.89$ のイオンの差は 0.50 Th の差になるのでしょうか $? 」$

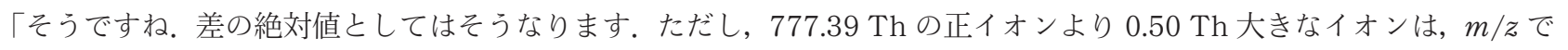
表記すると $m / z 777.89$ の正イオンですが, -777.39 Th の負イオンより 0.50 Th 大きなイオンは, $m / z$ で表記すると $m /$ $z 776.89$ の負イオンになります」

「この thomson という単位, 考え方としては『u/e』や『Da/e』と同じであるように思います，そして，質量電荷比と $m / z$ 之の問題を解決するために, thomson という新しい単位の導入を提案されたことについては, 私は評価すべきだと 思っています。しかし， RCM ではこの単位の使用は認められていますが，残念ながらそれほど普及屯していませんし， The International Union of Pure and Applied Chemistry (IUPAC) sponsored project to update and extend the definitions of terms related to the field of mass spectrometry, 国際純正・応用化学連合委託『質量分析関連用語標潐定 義改訂プロジェクト』のタスクグループ10),11) が起案した 3rd Draft ${ }^{12)}$ では, $m / z$ の定義文のところで “Note 2: The proposed unit thomson (Th) is deprecated.” と thomson を使用しないよう勧告しています」

「せっかく提案されたのに残念ですね」

「これからこの単位は今以上に使用されない方向に進んでいくように思います」 
「何が問題だったのでしょうか?

「そうですね. 詳しい説明は, O. D. Sparkman 著の “Mass Spectrometry Desk Reference”13)に記述されています。複 数の理由があると思いますが，私の印象としては，単位の定義の記述方法が少々曖昧すぎたかなと感じました，Atomic charge の明確な定義屯記載されていませんでした. 明確に $1 \mathrm{Th} \equiv 1 \mathrm{u} / \mathrm{e}$ と定義されていたわけであないようですし，どん な物理量の単位であるのかの定義も曖昧に感じました。単位名の記述法についても, daltonのような個人名に由来する単 位名屯, 固有名詞扱いをせずに dalton という形ですべて小文字で表記することになっていますが去), 6), 原著8)では thomsonではなくThomson と, daltonも Dalton と綴られていました」

「垂水先生が先程 Da を説明してくださった時に, daltonのd を小文字で書かれたのでちょっと不思議に思いましたが, そのようなルールがあったのですか」

「なかなか気づきにくいのですが。また無名数である分子量 molecular weightにuの単位がつけられていました，些細 なミスかむしれませんが，これらのことから，提案文自体が単位系のルールに㛜格ではない印象を与えてしまったのでは ないかと思います」

「その他にも, thomson という単位名, 電子の比電荷のお話をしたときに7)話題に上った Sir Joseph John Thomson に 敬意を表して命名されたのですが，Thomson という名の科学者は，J. J. Thomson 以外にもおられますので，Thomson の名前を冠した学術用語はいくつもあるようです. 私はよく知りませんが, Thomson coefficient トムソン係数という数 值むあるそうです。そのような用語，数值との区別が紛らわしいと思われたのでしょうか？」

「今お話した点以外にあ理由はあるように思いますが，IUPACからあ使用しないよう勧告されるようですので，残念な がらこの単位の使用頻度は激减すると思います。新しい単位を提案するという試みは評価に值するのですが，むっともっ といろいろな方々と議論を積み重ねてから提案すべきだったのかもしれません」

「新しい単位の提案というアクションは，科学の歴史を变えてしまうような一大事だと思います」

「単位の問題は本当に難しいです. 先日話題に上ったグリニッジの本初子午線のように ${ }^{14)}$, 人間が勝手に決めたことがた くさんあり, それが自然の摂理, 神様が決めたことにそぐわないこともあるのです. 生物の学名む, 人間が勝手につけたも のですから．須磨の海浜水族園のハンドゥイルカの『クー』，これもクーの意思とは関係なく，どなたかが名づけたのだと 思います。『クー』は学名ではありませんが, ハンドウイルカの学名は, Tursiops truncatus です。学名む物理量と同様に イタリック体で表記するというルールがあります」

「学名はラテン語ですが, Tursiops truncatus とはどういう意味でしょうか?」

「イルカのくちばしのような部分を『吻』と呼びますが, ハンドウイルカの大きな特徴として, この吻が太くて短い点が 挙げられます（写真 1,2). ハンドウイルカ, 英語では bottlenose dolphin といいます.この Tursiops truncatus という

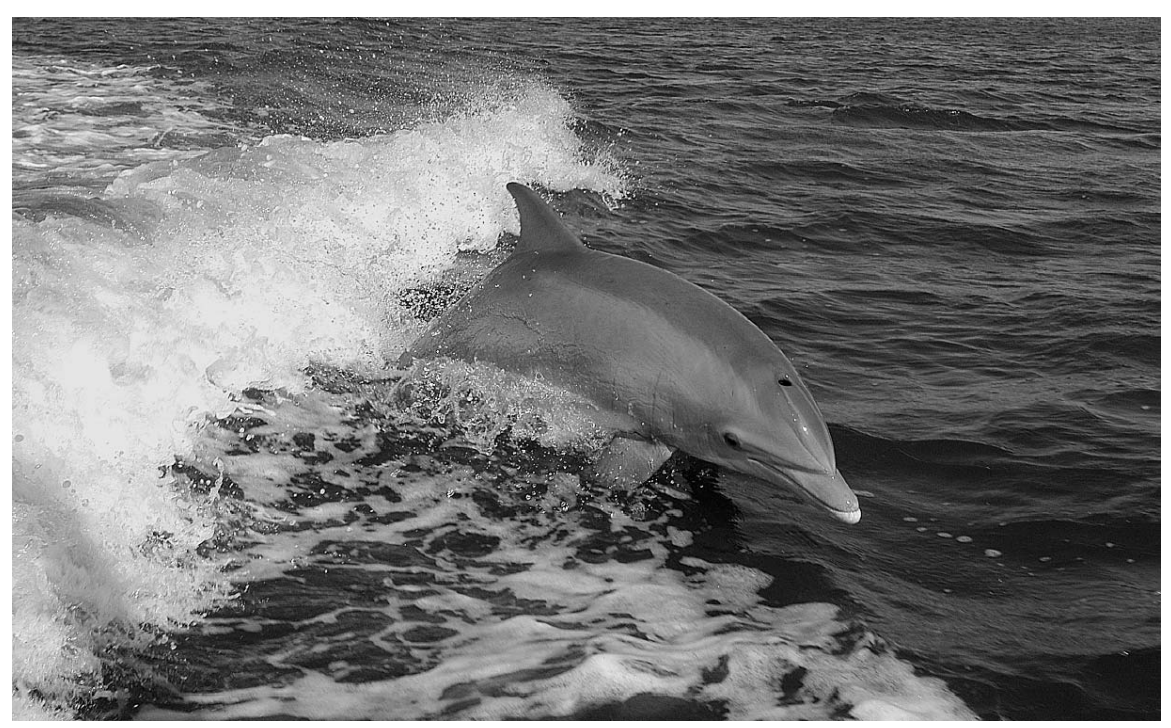

写真 1. 野生のハンドウイルカ Tursiops truncatus. (National Aeronautics and Space Administration, Photo No. KSC-04PD0178; URL:〈http://mediaarchive.ksc.nasa.gov/detail.cfm?mediaid=21807〉に掲載の著作権フリーの写真を改变, 転 載)

‡SI の国際文書には, 英語における単位の名称の表記法として, 文章の最初や大文字で表される表題で用いられる場合を除き, 単位の 名称の綴にはすべて小文字を用いる規定が明記されている。ただし, セルシウス度 $\left({ }^{\circ} \mathrm{C}\right)$ だけは例外であり, その名称の綴は degree Celsius である。「単位 degree は小文字のd からはじまり, その修飾詞である Celsius は人名に由来するので大文字のCからはじま る」と記されている. 


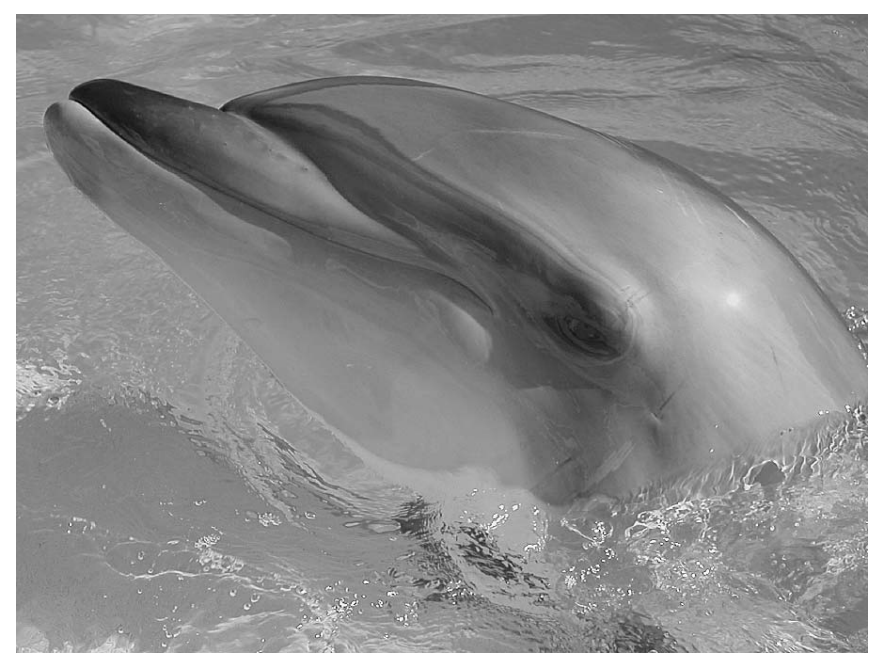

写真 2. ハンドウイルカ Tursiops truncatus の頭部。(URL:〈http://www.sxc.hu/photo/206725〉に掲載の著作権フリーの写真 を転載)

学名は『吻が断ち切られたイルカ』という意味だそうです」

「なるほど」

「屯ちろんこの学名屯『クー』同様に人間がイルカたちの意思とは関係なくつけた名前です.八ンドウイルカたちはこの 名前を知ったらどう思うでしょうか?」

「きっと，あっと格好いい名前を付けてよう！と思っているのではないでしょうか？『ジャンプが得意なイルカ』や， 『大海原を華麗に泳ぐイルカ』のような名前がいいなと，イルカたちは私たち人間のことをどのように名付けているので しょうか?」

「朝霧さん，私たちヒトの学名，ご存じですか？」

「Homo sapiens です」

「そうですね. このラテン語，どういう意味か，ご存じですか？」

「確か，『賢い人』という意味では?」

「そのとおりです。でもこの学名む, 神様ではなく, 人間が勝手につけたのです。神様が決めたこと, 自然の摂理に合致 した命名であるのか否かは，われわれ人類には判断できないことです」

「命名した方が抱いている，人類に対する切なる願いかもしれませんね」

「人類はもっと賢くならなければいけないと．朝霧さんらしいコメントですね」

\section{文献}

1) “化学大辞典”, 大木道則, 大沢利明, 田中元治, 千原秀明編, 東京化学同人, 東京 (1989).

2) “理化学辞典 (第 5 版)”, 長倉三郎, 井口洋夫, 江沢 洋, 岩村 秀, 佐藤文隆, 久保亮五編, 岩波書店, 東京 (1999).

3）笠間健嗣，“これならわかるマススペクトロメトリー”，化学同人，京都 (2001), p. 17.

4）笠間健嗣，“これならわかるマススペクトロメトリー”，化学同人，京都 (2001), p. 41.

5) "Le Système international d'unités (SI), 8 e édition/The International System of Units (SI), 8th edition," ed. by Bureau international des poids et mesures, STEDI Media, Paris (2006), URL: 〈http://www.bipm.fr/utils/common/pdf/si_brochure_ 8.pdf $>$.

6) 国際単位系 (SI) 日本語版, 国際文書第 8 版 (2006), 独立行政法人産業技術総合研究所計量標準総合センター訳・監修, URL: $\langle$ http://www.nmij.jp/chishiki/SI_8j.pdf $\rangle$.

7) 吉野健一，J. Mass Spectrom. Soc. Jpn., 54, 219 (2006).

8) R. G. Cooks and A. L. Rockwood, Rapid Commun. Mass Spectrom., 5, 93 (1991).

9) 内藤康秀, 吉野健一, J. Mass Spectrom. Soc. Jpn., 54, 218 (2006).

10) URL: 〈http://www.iupac.org/projects/2003/2003-056-2-500.html〉.

11) 内藤康秀, J. Mass Spectrom. Soc. Jpn., 54, 25 (2006).

12) K. K. Murray, R. K. Boyd, M. N. Eberlin, G. J. Langley, L. Li, and Y. Naito, Standard Definitions of Terms Relating to Mass Spectrometry (3rd Draft Document, August 2006) (2006), URL: 〈http://www.msterms.com/docs/IUPAC_MS_Terms_Third_ Draft.pdf $\rangle$.

13) O. D. Sparkman, "Mass Spectrometry Desk Reference, 2nd Edition," Global View Publishing, Pittsburgh (2006), p. 47.

14) 吉野健一, J. Mass Spectrom. Soc. Jpn., 54, 259 (2006).

Keywords: Abscissa, Mass spectra, dalton, thomson, $m / z$ 


\section{お詫びと訂正}

これまで, 今号掲載分を含め 7 回にわたり「目から鱗のマススペクトロメトリー」を連載して参りました。 これまでの連 載の中で, 明らかな誤記がございましたので, 心からの扔詫びを申し上げるとともに, 謹んで下記の正誤表のとおりに訂正 いたします。

\begin{tabular}{|c|c|c|}
\hline 巻, ページ数, 抒よび行数 & (誤) & (正) \\
\hline 54, p. 176, 下から 22 行目 & The International Union for & The International Union of \\
\hline 54, p. 221, 上から 12 行目 & The International Union for & The International Union of \\
\hline 54, p. 226, 下から 2 行目 & 異なることが問題なのです. & 異なることなのです。 \\
\hline 54, p. 260, 下から 6 行目 & The International Union for & The International Union of \\
\hline 54, p. 268, 下から 17 行目 & 国際単位系のルールー & 国際単位系のルール \\
\hline 54, p. 269, 上から 9 行目 & 1984 年, 明治 17 年 & 1884 年, 明治 17 年 \\
\hline 54, p. 269, 下から 9 行目 & 1986 年, 明治 19 年 & 1886 年, 明治 19 年 \\
\hline
\end{tabular}

IUPAC の名称の「of」と「for」との誤りは, 一度入力ミスをした原稿を何度もコピー・ペーストしていたがために, 重 ねてミスを犯すという初歩的な䛊りで, 用語の誤用を諭すための解説の著者としてはまったく挍恥ずかしい限りです.

筆者自らの失敗や誤解の経験の反省の念をこめて, この連載を始めましたが, 筆者自身, 用語の使い方に絶対の自信を あっているわけではございません。このような筆者ですから，「目から鱗のマススペクトロメトリー」という拙著を執筆し ている過程でも，数多くの文献や資料を調へ，常に用語や単位についての自らの理解を深める作業が続いております。ま た, 神様が創った自然の摂理そのものは何ら変化してはいないのですが, 人類の知識が質的にも量的にも変化し, 考え方も 変遷していく過程で, われわれが自然の摂理を考えたり書き表したりする際に用いる用語や単位も変遷していきます。文 中で何度も紹介した IUPAC のプロジェクトチームによる質量分析関連用語の標準定義改訂作業は, この連載を始めた時 点ではまだ完了しておらず, 作業が佳境を迎えている頃でした. 連載期間中に, 草稿の中の定義文が変更されたり, 日本質 量分析学会の用語委員会での議論の過程で, 用語の日本語表記, 日本語訳の変更があったりなど, たった 1 年の短い間で すが, 質量分析関連用語を取り巻く状況は常に変化していきました。 それゆえに, 本連載に記述された内容にもいくつか蔹

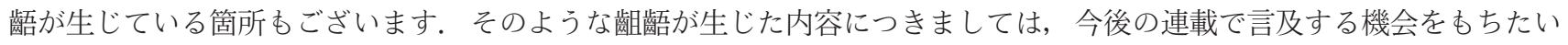
と考えております. また連載がある程度まとまった時点で, あう一度内容を精査し, 一貫性のある記述に訂正し, 加筆した 文書として発表することも考えております。

今後とも「目から鱗のマススペクトロメトリー」をご愛読のほど，よろしく㹉願いいたします。 